\title{
Temporal variation of mercury in Turkish Black Sea waters and associated risk assessment
}

\author{
Ustun Odabaşı S. ${ }^{1}$, Şentürk i. ${ }^{2}$, Maryam B. ${ }^{1}$, Akbal F. ${ }^{1}$, Bakan G. ${ }^{1}$ and Büyükgüngör H. ${ }^{1}$ \\ ${ }^{1}$ Faculty of Engineering Department of Environmental Engineering, Ondokuz Mayis University, Samsun, Turkey, 55200 \\ ${ }^{2}$ Cumhuriyet University, Faculty of Engineering, Department of Environmental Engineering, Sivas, Turkey, 58140 \\ Received: 15/11/2017, Accepted: 18/03/2018, Available online: 06/07/2018 \\ *to whom all correspondence should be addressed: e-mail: sevde.ustun@omu.edu.tr
}

\section{Abstract}

Presence of metals even at trace levels in natural waters pose sever health risks. Heavy metals are introduced to coastal and marine environments through a variety of sources and activities including sewage and industrial effluents where Black Sea is not different. However, metals behave differently in Black Sea as it an enclosed body. Coastal areas of Turkey face great challenges due to heavy metal contamination caused by rapid urbanization and industrialization. The aim of this study was to investigate the spatial and temporal distributions of total mercury $(\mathrm{Hg})$ in seawater at the mid-Black Sea coast of Samsun, Turkey. The samples were collected from 13 monitoring stations, from the three distances in four seasons during the year 2013. The samples were analyzed for physicochemical parameters along with contamination and enrichment factors. The distribution of $\mathrm{Hg}$ is nearly random along the studied coast but obtained values ranges from 0.57 to 12.6 $\mu \mathrm{g} / \mathrm{L}$ with an average of $5.24 \mu \mathrm{g} / \mathrm{L}$ were above permissible limits. It was observed that number of samples collected during wet seasons (winter and autumn) with $\mathrm{Hg}$ were higher. High enrichment factor 0.331 and contamination factor 25.2 was recorded. $\mathrm{Hg}$ present at sampling station M27 was due to point source, a possible ship activity indicated by enrichment factor. The sources responsible for water pollution with $\mathrm{Hg}$ are mainly municipal and industrial effluents, leaching, agricultural and pasturage runoff and oil spills. Furthermore, due to unique hydrography of Black Sea, risk of $\mathrm{Hg}$ accumulation is high. Interestingly, a direct relation between basicity and $\mathrm{Hg}$ concentration was observed. i.e. highest concentration was found on $\mathrm{pH} 8.33$.

Key words: Black Sea, Surface water quality, Mercury, Physico-chemical parameters, Enrichment factor, Contamination factor

\section{Introduction}

Metals are natural constituents of our surroundings and regarded as serious pollutant if present above a toxicity threshold (Hoda and Khaled 2009; Mashiatullah et al., 2013) but their traits of being persistent and bioaccumulation/biomagnification in the food chain is of greater concern (USEPA, 1997). Their deposition in aquatic environment can cause toxicity to aquatic biota (Lin et al., 2013) because ocean plays an important role in the global pollution cycling. Higher the trophic position along food chains or web, higher biomagnifications level in the organisms (Cheng, 2013; Tao et al., 2016) resulting in extremely high concentrations in large carnivorous fish such as tuna, shark, grouper and swordfish, posing potential health risks to consumers (Man et al., 2014). Among several coastal pollution types, trace metal pollution like, $\mathrm{Hg}$ input to the ocean is broadly driven by its physical, chemical, and biological dispersal, specifically by wet/dry deposition (Srichandan et al., 2016; Mason and Sheu, 2002; AMAP, 2011; Fisher et al., 2012; Kirk et al., 2012; Sonke et al., 2013; Sunderland and Mason 2007).

The coastal waters of most of the regions of the world ocean are under risk of $\mathrm{Hg}$ pollution due to increase in coastal migration of human population, anthropogenic activities like establishment of industries prompting excessive use of seawater and sea-based resources coupled with disposal of domestic and industrial wastes (Buddemeier et al., 2002). Hg pollution has attracted much attention because of the various acute or chronic toxicities of $\mathrm{Hg}$ in marine organism and humans and its increasingly widespread presence (Renault, 2015). It has been reported that even low doses of $\mathrm{Hg}$ can damage different organ systems, like the nervous system, the motor system, the cardiovascular system, and the kidney system (Zahir et al., 2005; Lin et al., 2013). A recent study showed that mercurial compounds would readily cross the placental barrier and the blood-brain barrier, damaging the developing brain of fetus (Christinal and Sumathi 2013) later accumulating to the hair of children (Abdullah et al., 2012; Ko et al., 2012). In fact, $\mathrm{Hg}$ in ocean waters originates from different sources and occurs as different chemical species, including inorganic (e.g., $\mathrm{Hg}$ (I) or $\mathrm{Hg}$ (II)) and organic (e.g., methyl mercury (MeHg), ethyl mercury (EtHg), and phenyl mercury (pHHg). The most important source is reduction of $\mathrm{Hg}$ (II) by aquatic microorganisms and photo reduction (Mason et al., 1995; Amyot et al., 1997; Costa and Liss 1999, 2000). 10-30\% of total Hg can be present as elemental $\mathrm{Hg}$ in oceanic waters (Kim and Fitzgerald, 1988; Mason et al., 1993). It has been proved that mercury with different forms exhibited quite different 
toxicities, but organic $\mathrm{Hg}$ compounds are more toxic than inorganic species (Leopold et al., 2010). Even considering threat of $\mathrm{MeHg}$ in fish, public health professionals issued consumption advisories to minimize possible health risks (RIDOH, 2016; US FDA, 2016).

The Black Sea is fed by several large rivers originating in Europe and Asia. The total fresh water input to the Black Sea from a large number of small and big rivers and streams is $353 \mathrm{~km}^{3} \mathrm{y}^{-1}$ (Yigiterhan and Murray, 2008; Akbal et al., 2011). The surface layer of its waters displays relatively low salinity (Ergul et al., 2008). The bottom water layer (at depths approx. $100 \mathrm{~m}$ ) is more saline and is maintained by Mediterranean water entering through the Bosphorus strait (Lee et al., 2002). Furthermore, these two water layers are separated by a strong density gradient, which limits exchange between them (Ergul et al., 2008).

Black Sea not only has been increasingly threatened by pollutants over the past decades as a result of accidental crude oil spills, dumping of toxic industrial wastes, discharge of domestic wastes from coastal settlements, roads and industrial and domestic pollutants carried by rivers, but also due to excessive fresh water input it is less saline (Ergul H.A. et al., 2008) which is important for $\mathrm{Hg}$ dispersion (Bozcaarmutlu et al., 2009). Meanwhile, metals in the marine environment are associated with various adsorption mechanisms including precipitation, ion exchange, complexation and partition (Chen $\mathrm{H}$. et al., 2016). It is well-known that a number of chemical, physical, biological and hydrodynamic parameters can affect the vertical transport of sinking particles (Heussner et al., 1988).

The high salinity of seawater enhances the aggregation of suspended particles, resulting in more rapid sedimentation of heavy metals (Du Laing et al., 2009) that is the reason, water and soil/sediments in harbors and estuaries serve as a pool for heavy metals to be adsorbed, accumulated, and released to nearby and overlying areas (Guerra-Garcia and Garcia-Gomez 2005; Chen et al., 2007) but in case of Black sea and its low salinity degree of metals dispersion and sinking to sediments is low and enrichment into upper layer is high.

Research has shown that elevated water temperatures, low $\mathrm{pH}$, anaerobic conditions, and higher dissolved organic carbon concentrations increase rates of methylation of $\mathrm{Hg}$ (US Environmental Protection Agency, 1997; Power M., et al., 2002). Under anaerobic conditions, bacteria within fine-grained and organic sediments can transform elemental $\mathrm{Hg}$ into methylmercury, a highly toxic organic form of $\mathrm{Hg}$. Changes in environmental conditions $(\mathrm{pH}$, ionic strength, redox potential or biological activities) may cause the mobilization of adsorbed metal/metalloid into the liquid phase and the subsequent contamination of seawater (Horvat et al., 2003). Enough work has been published concerning heavy metal concentrations in surface sediments or sediments samples from different parts of the Turkish coast of the Black Sea (Yucesoy and Ergin, 1992; Guven et al., 1993; Topcuoglu et al., 2002, 2003), however little attention was paid to common features among heavy metal pollution sources and mechanisms in the upper layers of sea water and meanwhile, studies based on the data collected from the open sea are limited (Chen et al., 2016).

The methylating activity of $\mathrm{Hg}$ is usually lower in marine than in freshwater environments due to salinity effects and the presence of charged sulphide and chloride complexes. Reducing conditions and high salinity promote demethylation processes (Compeau and Bartha, 1987; Hines et al., 2000). The observed increase of $\mathrm{MeHg}$ towards the bottom could be the consequence of photochemical degradation and/or microbial actions in surface waters. In deeper waters particulate dissolution releases $\mathrm{MeHg}$ and inorganic $\mathrm{Hg}$ into solution (Cossa et al., 1997). The highest concentrations of methylated $\mathrm{Hg}$ species are present in deeper water masses. The chemical form of $\mathrm{Hg}$ in the ocean environment strongly depends on redox and $\mathrm{pH}$ conditions, as well as on the concentrations of inorganic and organic complexing agents (Horvat et al., 2003). Temporal variations, such as weather conditions, temperature, water chemistry, etc. can also affect $\mathrm{Hg}$ speciation (Kotnik et al., 2007).

Considering the human health risks of intake of $\mathrm{Hg}$ via fish consumption or other recreational activities near coast, the present study focused on the investigation of $\mathrm{Hg}$ present in seawater by taking seasonal samples from busy mid-Black Sea coastal areas of Samsun, Ordu and Sinop, Turkey.

\section{Material and Method}

\subsection{Study Area}

The Black Sea coast of Turkey is 1,695 km long, extending from Bulgarian border in the west to the Georgian border in the east. The area of the region is about $141,000 \mathrm{~km} 2$ or about $18 \%$ of the total surface area of Turkey. In the Black Sea Region of Turkey almost every kind of industrial unit (food, fisheries, cement, paper, fertilizer, pesticide, resin, plastic, textile, tobacco) is working that are the potential source of pollution (Bakan and Buyukgungor, 2000; Altas and Buyukgungor, 2007). Figure 1 shows the cities (Samsun, Ordu and Sinop) and major rivers and tributaries that are the focus of present research. It is to be noted that Samsun is one of the largest city of Black sea region with population of 1279884 according to TUIK (TUIK, 2015).

Figure 1 shows the map of the examined area and monitoring locations in this study along with the encircled sampling station where $\mathrm{Hg}$ was detected. It was our primary concern to collect samples from or near the discharging points of rivers and streams that fall into Black Sea. Samples were taken and analyzed in the months of January, April, July and November 2013 from 13 main locations from open sea near coastal area as shown in Figure 1. Samples were taken in a way that 3 distances; Short distance $500 \mathrm{~m}(0.5 \mathrm{~km})$, mid distance 3 mile $(4.8 \mathrm{~km})$ and long distance 20 mile $(32.1 \mathrm{~km})$ were selected to understand the dispersion or dilution of pollutants. This way in 4 seasons from multiple distances a sum total of 156 samples were collected out them only some samples were detected with $\mathrm{Hg}$. Location detail of $\mathrm{Hg}$ contained samples are given in Table 1 according to latitude and longitude which were taken with the help of GPS. 


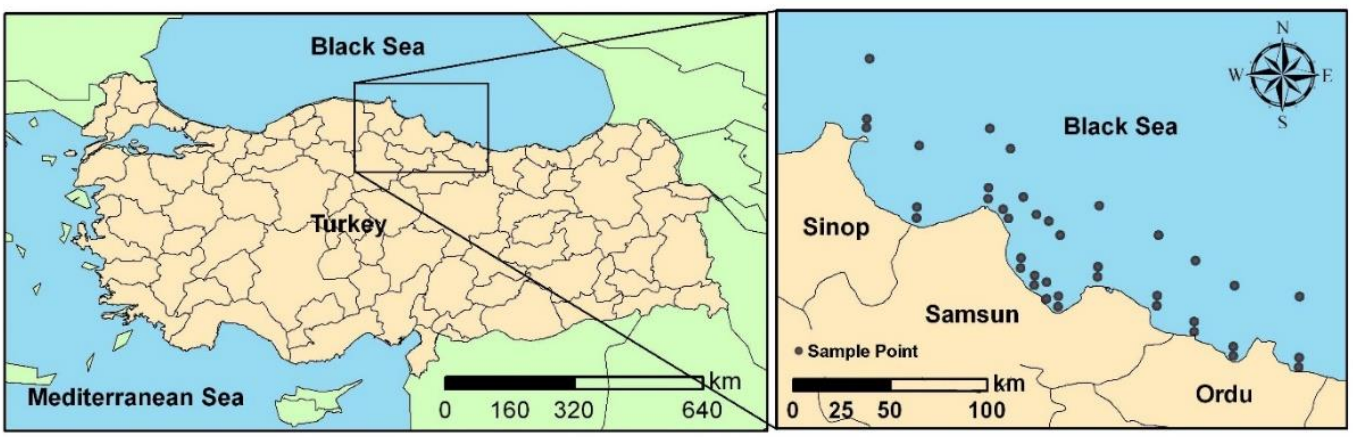

Figure 1. Sampling locations at 3 distances from the coast of Black Sea.

Table 1. Distances, codes, Latitude and longitude of sampling stations along with the detection of $\mathrm{Hg}$

\begin{tabular}{|c|c|c|c|c|}
\hline Sampling stations & Distance & Sample code & Latitude-Longitude & Detection of $\mathrm{Hg}$ \\
\hline \multirow{3}{*}{ Sinop } & $500 \mathrm{~m}$ & M1 & $42 \circ 02^{\prime} 58^{\prime \prime} \mathrm{N}-035 \circ 11^{\prime} 23^{\prime \prime} \mathrm{E}$ & Detected \\
\hline & 3 mile & $\mathrm{M} 2$ & 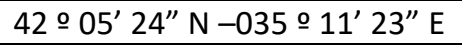 & - \\
\hline & 20 mile & M3 & $42 \div 22^{\prime} 12^{\prime \prime} \mathrm{N}-035 \div 11^{\prime} 23^{\prime \prime} \mathrm{E}$ & - \\
\hline \multirow{3}{*}{ Yakakent } & $500 \mathrm{~m}$ & M4 & $41 \cong 38^{\prime} 18^{\prime \prime} \mathrm{N}-035 \div 31^{\prime} 24^{\prime \prime} \mathrm{E}$ & - \\
\hline & 3 mile & M5 & $41 \cong 41^{\prime} 24^{\prime \prime} \mathrm{N}-035 \cong 31^{\prime} 24^{\prime \prime} \mathrm{E}$ & - \\
\hline & 20 mile & M6 & $41 \div 58^{\prime} 30^{\prime \prime} \mathrm{N}-035 \circ 31^{\prime} 24^{\prime \prime} \mathrm{E}$ & - \\
\hline \multirow{3}{*}{ Bafra (Kızılırmak) } & $500 \mathrm{~m}$ & M7 & $41 \cong 44^{\prime} 32^{\prime \prime} \mathrm{N}-035 \circ 57^{\prime} 50^{\prime \prime} \mathrm{E}$ & - \\
\hline & 3 mile & M8 & $41 \cong 47^{\prime} 35^{\prime \prime} \mathrm{N}-035 \cong 57^{\prime} 50^{\prime \prime} \mathrm{E}$ & - \\
\hline & 20 mile & M9 & $42 \div 04^{\prime} 35^{\prime \prime} \mathrm{N}-035 \cong 57^{\prime} 50^{\prime \prime} \mathrm{E}$ & Detected \\
\hline \multirow{3}{*}{ Engiz } & $500 \mathrm{~m}$ & M10 & $41 \cong 39^{\prime} 10^{\prime \prime} \mathrm{N}-036 \div 05^{\prime} 30^{\prime \prime} \mathrm{E}$ & - \\
\hline & 3 mile & M11 & $41 \cong 41^{\prime} 40^{\prime \prime} \mathrm{N}-036$ 우의 $30^{\prime \prime} \mathrm{E}$ & Detected \\
\hline & 20 mile & M12 & $41 \cong 58^{\prime} 40^{\prime \prime} \mathrm{N}-036 \div 05^{\prime} 30^{\prime \prime} \mathrm{E}$ & - \\
\hline \multirow{3}{*}{ Kurupelit } & $500 \mathrm{~m}$ & M13 & $41 \cong 25^{\prime} 30^{\prime \prime} \mathrm{N}-036 \cong 10^{\prime} 45^{\prime \prime} \mathrm{E}$ & - \\
\hline & 3 mile & M14 & $41 \cong 28^{\prime} 15^{\prime \prime} \mathrm{N}-036 \cong 10^{\prime} 45^{\prime \prime} \mathrm{E}$ & - \\
\hline & 20 mile & M15 & $41 \cong 45^{\prime} 15^{\prime \prime} \mathrm{N}-036 \cong 10^{\prime} 45^{\prime \prime} \mathrm{E}$ & - \\
\hline \multirow{3}{*}{ Atakum } & $500 \mathrm{~m}$ & M16 & 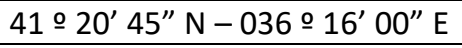 & - \\
\hline & 3 mile & M17 & 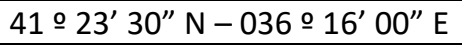 & Detected \\
\hline & 20 mile & M18 & 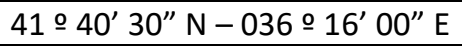 & - \\
\hline \multirow{3}{*}{ Samsun Harbour } & $500 \mathrm{~m}$ & M19 & $41 \cong 21^{\prime} 45^{\prime \prime} \mathrm{N}-036 \div 20^{\prime} 30^{\prime \prime} \mathrm{E}$ & Detected \\
\hline & 3 mile & M20 & $41 \cong 21^{\prime} 45^{\prime \prime} \mathrm{N}-036 \cong 20^{\prime} 30^{\prime \prime} \mathrm{E}$ & - \\
\hline & 20 mile & $\mathrm{M} 21$ & 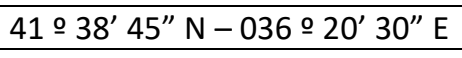 & - \\
\hline \multirow{3}{*}{ Kutlukent (OIZ) } & $500 \mathrm{~m}$ & M22 & $41 \cong 15^{\prime} 00^{\prime \prime} \mathrm{N}-036 \div 25^{\prime} 00^{\prime \prime} \mathrm{E}$ & - \\
\hline & 3 mile & M23 & $41 \cong 18^{\prime} 00^{\prime \prime} \mathrm{N}-036 \div 25^{\prime} 00^{\prime \prime} \mathrm{E}$ & Detected \\
\hline & 20 mile & M24 & 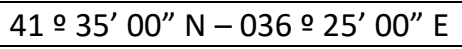 & - \\
\hline \multirow{3}{*}{$\begin{array}{l}\text { Çarşamba } \\
\text { (Yeşilırmak) }\end{array}$} & $500 \mathrm{~m}$ & $\mathrm{M} 25$ & $41 \cong 23^{\prime} 40^{\prime \prime} \mathrm{N}-036 \div 39^{\prime} 15^{\prime \prime} \mathrm{E}$ & - \\
\hline & 3 mile & M26 & $41 \cong 26^{\prime} 30^{\prime \prime} \mathrm{N}-036 \div 39^{\prime} 15^{\prime \prime} \mathrm{E}$ & Detected \\
\hline & 20 mile & M27 & $41 \cong 43^{\prime} 30^{\prime \prime} \mathrm{N}-036 \div 39^{\prime} 15^{\prime \prime} \mathrm{E}$ & Detected \\
\hline \multirow{3}{*}{ Terme } & $500 \mathrm{~m}$ & M28 & $41 \cong 16^{\prime} 00^{\prime \prime} \mathrm{N}-037 \div 01^{\prime} 30^{\prime \prime} \mathrm{E}$ & - \\
\hline & 3 mile & M29 & 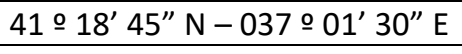 & Detected \\
\hline & 20 mile & M30 & $41 \cong 35^{\prime} 45^{\prime \prime} \mathrm{N}-037 \div 01^{\prime} 30^{\prime \prime} \mathrm{E}$ & - \\
\hline \multirow{3}{*}{ Ünye } & $500 \mathrm{~m}$ & M31 & 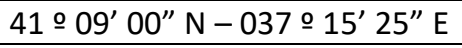 & - \\
\hline & 3 mile & M32 & 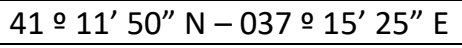 & - \\
\hline & 20 mile & M33 & 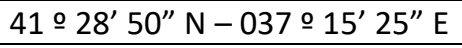 & - \\
\hline \multirow{3}{*}{ Fatsa } & $500 \mathrm{~m}$ & M34 & 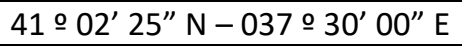 & - \\
\hline & 3 mile & M35 & 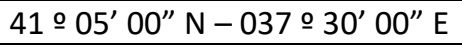 & - \\
\hline & 20 mile & M36 & 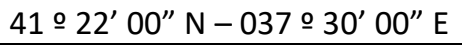 & - \\
\hline \multirow{3}{*}{ Ordu } & $500 \mathrm{~m}$ & M37 & 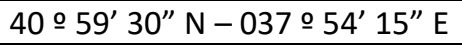 & Detected \\
\hline & 3 mile & M38 & 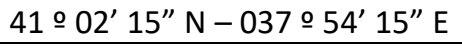 & - \\
\hline & 20 mile & M39 & 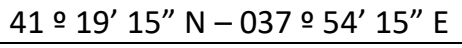 & Detected \\
\hline
\end{tabular}




\subsection{Seawater sampling, processing and analysis}

Samples were taken from almost 1-meter depth with the help of Nansen bottle. 5 liter plastic bottles used to collect seawater whıch were pre-washed using $10 \%$ nitric acid followed by oven drying at $40{ }^{\circ} \mathrm{C}$ for subsequent analysis in the laboratory while $100 \mathrm{ml}$ brown glass bottles were used to store seawater samples further metal analysis at $4^{\circ} \mathrm{C}$. Before the tests, samples were filtered using membrane filter of pore size $45 \mu \mathrm{m}$. For seawater sampling, water quality parameters including temperature, salinity, TDS (Total Dissolved Solids) and dissolved oxygen were analyzed on-site by using a water quality sensor CONSORT C535. $\mathrm{NO}_{3}-\mathrm{N}$ and $\mathrm{NH}_{4}-\mathrm{N}$ were analyzed by using UV/VIS spectrophotometer (PG-T70UV/VIS). Obtained samples were analyzed on the same day or the next for parameters like TOC with the help of APOLLO 9000 TOC analyzer. After that $\mathrm{Hg}$ analyses were performed with ICP-OES that is usually preferred for the analysis of heavy metals. In this study, LGC standard Nass- 6 standard reference material was used for ICP-OES measurements.

\subsection{Enrichment Factor (EF)}

Enrichment factor (EF) was employed to assess the degree of contamination and to understand the distribution of the elements of anthropogenic origin from study area by the background values (natural origins) (Simex and Helz, 1981). Reference values of heavy metal concentrations were determined as the period of minor anthropogenic pressure (Zalewska et al., 2015). Fe was chosen as the normalizing element while determining EF values since it is mainly supplied element in water and is one of the widely used reference element (Loska et al., 2003; Kothai et al., 2009; Chakravarty and Patgiri, 2009; Seshan et al., 2010). To illustrate the temporal changes of $\mathrm{Hg}$ concentrations in the upper layer of seawater in comparison to the background values, following formula was used:

Table 2. Enrichment factor categories (Sutherland et al., 2000).

\begin{tabular}{cc}
\hline EF ranges & Status description \\
\hline $\mathrm{EF}<2$ & Deficiently to minimal enrichment \\
\hline $2 \leq \mathrm{EF}<5$ & Moderate enrichment \\
\hline $5 \leq \mathrm{EF}<20$ & Significant enrichment \\
\hline $20 \leq \mathrm{EF}<40$ & Very high enrichment \\
\hline $\mathrm{EF} \geq 40$ & Extremely high enrichment \\
\hline
\end{tabular}

Enrichment factor $=(\mathrm{Cn} / \mathrm{Fe})$ sample $/(\mathrm{Cn} / \mathrm{Fe})$ background where, $\mathrm{Cn}$ is the concentration of element " $\mathrm{n}$ ". (Turekian and Wedepohl, 1961). Elements which are naturally derived have an EF value of nearly unity, while elements of anthropogenic origin have EF values of several orders of magnitude. (Mashiatullah et al., 2013; Loska et al., 2003) have defined a criteria of low occurrence variability and the presence in trace amount in the environment for the consideration reference element. Elements that are available in a considerable amount in the environment (such as Fe and $\mathrm{Al}$ ) can also be used as long as it does not have any synergy or antagonistic effect on the metal that is being evaluated (Loska et al., 2003; Hazzeman, 2013). Background value for $\mathrm{Hg}$ was decided according to the study done by (Oste et al., 2012). Enrichment factor categories are shown in Table 2, proposed by Sutherland et al., in 2000.

\subsection{Contamination Factor (CF)}

The method of CF calculation is identical to EF calculation. The contamination factor was applied to evaluate the degree of pollution, by comparing tested levels to a special period, such as the preindustrial period (Hakänson, 1980) or a relatively undisturbed period of that specific area. The aim of calculating contamination factor is to provide a measure of the degree of overall contamination of surface layers in a sampled site. The contamination factor was calculated using the following ratio:

$\mathrm{CF}=\mathrm{CFn}$ (sample)/ Cbn (background)

Where $\mathrm{Cn}$ is the contamination factor of metal " $\mathrm{n}$ " $\mathrm{Cbn}$ is time-scale background level of " $n$ ". Contamination factors and degree of contamination categories are given in Table3.

Table 3. Seawater quality classifications based on contamination factor (Birch and Olmos, 2008; Zahra et al., 2014).

\begin{tabular}{cc}
\hline CF ranges & Status description \\
\hline $\mathrm{CF} \geq 10$ & Bad \\
\hline $5 \leq \mathrm{CF}<10$ & poor \\
\hline $1 \leq \mathrm{CF}<5$ & Moderate \\
\hline $0.5 \leq \mathrm{CF}<1$ & Good \\
\hline $0<\mathrm{CF}<0.5$ & Very good \\
\hline
\end{tabular}

\section{Results and Discussion}

Total 156 samples from 13 sampling sites were collected and analyzed for $\mathrm{Hg}$ and physicochemical properties but out of 156 sample only 11 samples were found to have $\mathrm{Hg}$ in them. Obtained values of $\mathrm{Hg}$ are given in a detailed Table 4 along with physicochemical properties and calculated enrichment factor and contamination factor. In order to confirm the accuracy of the measurement results, the standard reference material known in the real value is used. In ICP-OES analyzes, the limit of detection for $\mathrm{Hg}$ was $0.1 \mu \mathrm{g} / \mathrm{l}$. It is to be noted, only sampling sites, where $\mathrm{Hg}$ was detected are mentioned in the table along with the season of detection. Rest of the sample with zero or below detection limits of $\mathrm{Hg}$ are ignored for convenience.

$\mathrm{Hg}$ pollution and physicochemical parameters like temperature, $\mathrm{pH}$, total dissolved solids and dissolved oxygen levels were analyzed in different seasons to understand the temporal impacts on pollution dispersion. It was observed that number of samples collected during wet seasons (winter and autumn) with $\mathrm{Hg}$ are higher than the samples collected in dry seasons (spring and summer). These results agree with the results obtained by (Godwin et al., 2004; Dan et al., 2014). The higher levels of $\mathrm{Hg}$ is attributed with the nonpoint sources that bring in the trace metal with surface runoff and anthropogenic activities. $12.6(\mu \mathrm{g} / \mathrm{L})$ of $\mathrm{Hg}$ present at M27 in summer season is clearly due to some point source, that could be from a ship or an oil tanker. The accumulation of certain trace metals in water is directly or indirectly controlled by redox conditions through either a change in redox state and/or speciation. 
Table 4. Physicochemical and $\mathrm{Hg}$ analysis along with CF and EF Values of $\mathrm{Hg}$ in the sea water of Black Sea.

\begin{tabular}{|c|c|c|c|c|c|c|c|c|c|c|c|c|c|}
\hline $\begin{array}{l}\text { Sample } \\
\text { code }\end{array}$ & Sampling location & Season & Distance & $\mathrm{T}\left({ }^{\circ} \mathrm{C}\right)$ & pH & TDS (g/L) & $\mathrm{DO}$ (mg/L) & $\begin{array}{l}\mathrm{NO}_{3}-\mathrm{N} \\
(\mathrm{mg} / \mathrm{L})\end{array}$ & $\begin{array}{l}\mathrm{NH}_{4}-\mathrm{N} \\
(\mathrm{mg} / \mathrm{L})\end{array}$ & $\begin{array}{c}\text { TOC } \\
\text { (mg/L) }\end{array}$ & $\begin{array}{c}\text { Hg conc. } \\
(\mu \mathrm{g} / \mathrm{L})\end{array}$ & $* * \mathrm{EF}$ & $* \mathrm{CF}$ \\
\hline M1 & Sinop & Summer & $500 \mathrm{~m}$ & 24.90 & 8.27 & 17.57 & 7.50 & 0.00 & 0.002 & 2.6494 & 0.57 & 0.007 & 1.14 \\
\hline M9 & Bafra-kızılırmak & Autumn & 20 mile & 25.00 & 8.28 & 17.13 & 7.72 & 0.00 & 0.000 & 3.7522 & 3.60 & 0.106 & 7.20 \\
\hline M11 & Engiz & Autumn & 3 mile & 24.60 & 8.36 & 17.41 & 7.89 & 0.00 & 0.000 & 2.9761 & 4.00 & 0.02 & 8.00 \\
\hline M17 & Atakum & Autumn & 3 mile & 26.50 & 8.3 & 17.38 & 8.18 & 0.00 & 0.093 & 2.5275 & 1.21 & 0 & 2.42 \\
\hline M19 & Samsun Harbour & Autumn & $500 \mathrm{~m}$ & 23.90 & 8.26 & 16.71 & 8.34 & 0.00 & 0.000 & 2.3442 & 3.40 & 0.032 & 6.80 \\
\hline $\mathrm{M} 23$ & Kutlukent-OIZ & Spring & 3 mile & 14.10 & 7.97 & 17.82 & 8.80 & 0.00 & 0.000 & 2.5207 & 1.79 & 0.009 & 3.58 \\
\hline M26 & Çarşamba-yeşilırmak & Winter & 3 mile & 14.10 & 8.36 & 17.4 & 8.46 & 0.00 & 0.000 & 2.6658 & 11.00 & 0.061 & 22.00 \\
\hline M27 & Çarşamba-yeşilırmak & Summer & 20 mile & 24.50 & 8.33 & 17.66 & 8.47 & 0.00 & 0.097 & 2.8546 & 12.60 & 0.331 & 25.20 \\
\hline M29 & Terme & Spring & 3 mile & 13.50 & 7.88 & 16.11 & 9.47 & 0.00 & 0.047 & 3.6113 & 6.20 & 0.166 & 12.40 \\
\hline M37 & Ordu & Winter & $500 \mathrm{~m}$ & 12.90 & 8.26 & 17.22 & 9.89 & 0.00 & 0.114 & 2.8254 & 5.10 & 0.064 & 10.20 \\
\hline \multirow[t]{4}{*}{ M39 } & Ordu & Winter & 20 mile & 12.30 & 8.26 & 16.21 & 9.81 & 0.00 & 0.061 & 2.6906 & 8.20 & 0.232 & 16.40 \\
\hline & Min & & & 12.30 & 7.88 & 16.11 & 7.50 & 0.00 & 0.000 & 2.3442 & 0.57 & 0 & 1.14 \\
\hline & Max & & & 26.50 & 8.36 & 17.82 & 9.89 & 0.00 & 0.114 & 3.7522 & 12.6 & 0.331 & 25.20 \\
\hline & Mean & & & 20.66 & 8.23 & 17.15 & 8.59 & 0.00 & 0.037 & 2.8562 & 5.24 & 0.09 & 10.49 \\
\hline
\end{tabular}

*Contamination Factor**Enrichment Factor 
The $\mathrm{pH}$ trend observed was slightly basic ranging from 7.88 to 8.23. The surface water temperature during summer and spring was higher than the temperature recorded in winter and autumn (Table 5). This indicated the level of pollutant at specific location in specific time. Usually in sea water $\mathrm{pH}$ value tries to get neutral over time with new water waves but higher $\mathrm{pH}$ supports $\mathrm{Hg}$ contamination. There are two possibilities for presence of metals in water, first, if water belong to an enclosed body it has been divided into layers as in the case of Black sea, the metals stay suspended into layers because of different chemistry between layers, second when metals are released into the marine environment, they are absorbed by organic matters and transferred to the sediments over time. Organic ligands, formed as the consequence of organic matter decomposition, may extract metals from sediments and mobilized them in the layers of water thus increasing their concentration in water (Seshan et al., 2010). Table 3 shows variation in $\mathrm{Hg}$ levels at different locations. Observed $\mathrm{Hg}$ levels in sea water samples were in the range of 0.57 to $12.6 \mu \mathrm{g} / \mathrm{L}$ with the mean value of $5.24 \mu \mathrm{g} / \mathrm{L}$. M27 in summer season was the location with highest detection. Our findings are in agreement with the studies mentioned in table 5 .

Table 5. Surface water $\mathrm{Hg}$ levels observed in some of the recent studies held for international sea waters.

\begin{tabular}{cccc}
\hline Serial No. & $\mathbf{H g}(\boldsymbol{\mu g} / \mathrm{L})$ & Location & Reference \\
\hline 1 & 0.0063 & Yangtze Estuary, China & Yin et al., 2015 \\
\hline 2 & $\mathrm{BDL}$ & Bay Of Bengal & Kibria et al., 2016 \\
\hline 3 & $0.19-0.44$ & Arut Island, Arabian Gulf & Al-Taani et al., 2014 \\
\hline 4 & $0.018-0.123$ & Jordanian Gulf of Aqaba & Youssef et al., 2016 \\
\hline 5 & $0.003-0.01$ & Red Sea & Sun et al., 2013 \\
\hline 6 & 0.25 & Bay of Xiamen, China & Tavares et al., 2016 \\
\hline 7 & $\mathrm{BDL}$ & Portuguese coast, at the Atlantic Ocean & Present study \\
\hline 8 & $0.57-12.6$ & Black Sea Coast of Turkey &
\end{tabular}

*BDL: Below Detection Limit

$\mathrm{Hg}$ was detected in same sea environment and seawater and was attributes to the surface runoff and anthropogenic activities in many studies conducted by researchers around the word. In the present study varying levels of $\mathrm{Hg}$ were detected from different locations in different seasons and some are dangerously high above the permissible limits of EPA and EU standards as illustrated in Figure 2. Permissible limit of $\mathrm{Hg}$ is defined as 0.5 , and $2 \mu \mathrm{g} / \mathrm{L}$ by EU, and EPA respectively. These alarming concentration of $\mathrm{Hg}$ in Black seawater is not only devastating for marine life especially which is present in aerobic section of Black sea and consumable contaminated fish is a potential risk for humans.

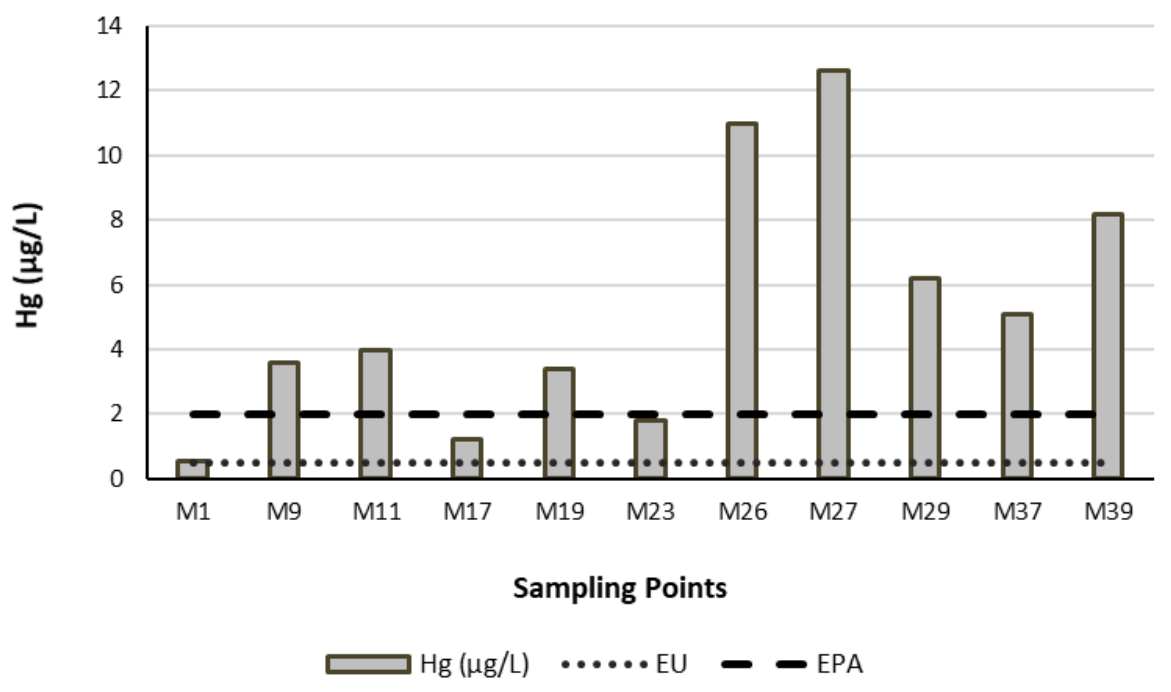

Figure 2. Permissible limits for $\mathrm{Hg}$ against observed levels of $\mathrm{Hg}$

In winter seasons high dissolved oxygen content was observed and likewise high $\mathrm{Hg}$ content, so it was assumed that high temperatures and $\mathrm{pH}$ stabilize $\mathrm{Hg}$ in surface water.

$\mathrm{Hg}$ pollution that was found at the distances of 500 meter (M1, M19 and M37) near to shore is considered to be carried out with surface run of or with the water tributaries but rest of higher concentration of $\mathrm{Hg}$ at distances 20 or 3 miles indicates localized surface sea water pollution.

\subsection{Enrichment factor of $\mathrm{Hg}$ in the sea water of Black Sea}

EF was employed to assess the degree of contamination and to understand the distribution of the elements of anthropogenic origin from sites. As anticipated, the seawater samples obtained in autumn and summer are 
more enriched with $\mathrm{Hg}$ than in summer and spring. $\mathrm{EF}$ calculated was in range from 0 to 0.331 . The higher value of EF shows the source is of anthropogenic nature while the lower values shows the source is sea itself. According to Enrichment factor categories proposed by (Sutherland, R. A., et al 2000) all the sample fall in less than two category $(E F<2)$ which means deficiently to minimal enrichment. This is possible because pollutants are constantly been washed up or diluted by the high tides and low tides. The highest EF was obtained for the sample M27 at the longest distance of 20 miles from coast (Figure 3). This the location where Yesilirmak river falls into Black sea and it clearly indicates that in this case river is not the cause in fact some point source pollution with in the open sea water in the form of waste dumping from ship carried out.

EF Graph

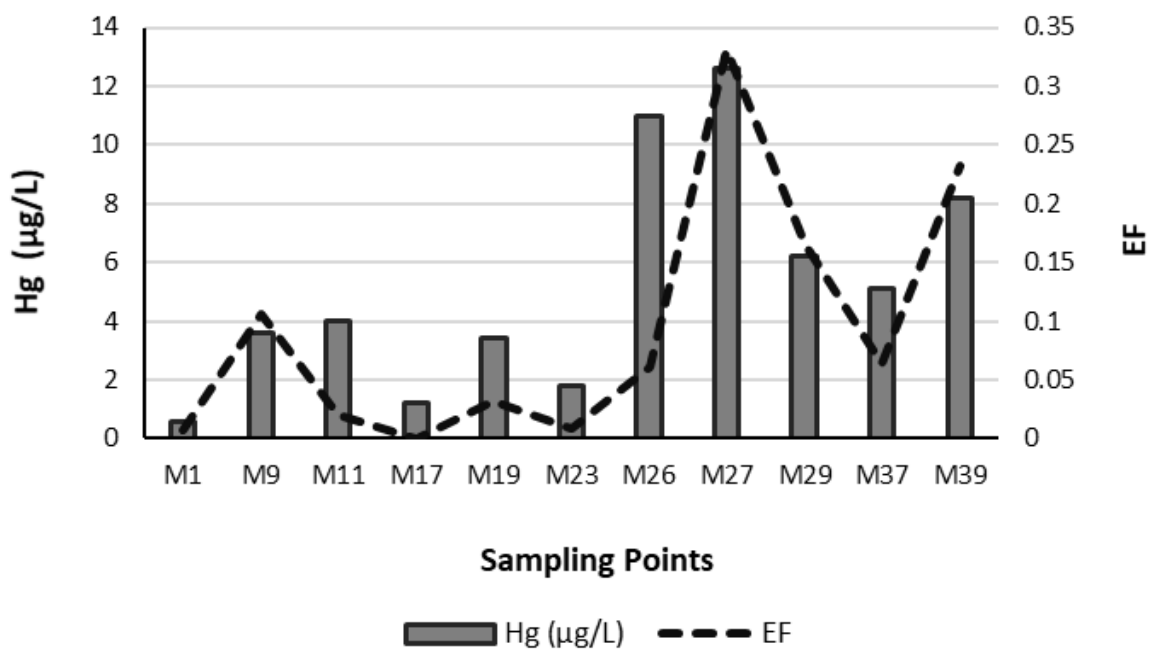

Figure 3. Enrichment factor of $\mathrm{Hg}$ at the Black Sea Coast of Turkey

\subsection{Contamination factor of $\mathrm{Hg}$ in the sea water of Black} Sea

The degree of contamination of surface sea water with $\mathrm{Hg}$ at different locations and distances are given in Figure 4. Highest $\mathrm{Hg}$ contamination was found at the distances of 3 and 20 miles (M26 and M27) both in winter and summer season that indicates localized $\mathrm{Hg}$ spill. It is to be noted that river may contribute elevated concentrations levels because Yeşilırmak River also falls into sea at this sampling site. The other high contamination factor was calculated for sampling location of Terme and Ordu in cold wet seasons when the dissolved oxygen level in the surface water of sea is higher. That may support $\mathrm{Hg}$ speciation and dispersion or binding $\mathrm{Hg}$ at a place for relatively longer period of time until the water layers get mixed. But in the case of sample M37 and M29 it is obvious that $\mathrm{Hg}$ pollution was carried out by river flow or runoff. One other thing we can infer that study area showed higher degree of contamination in winter seasons than in summer seasons.

\section{CF Graph}

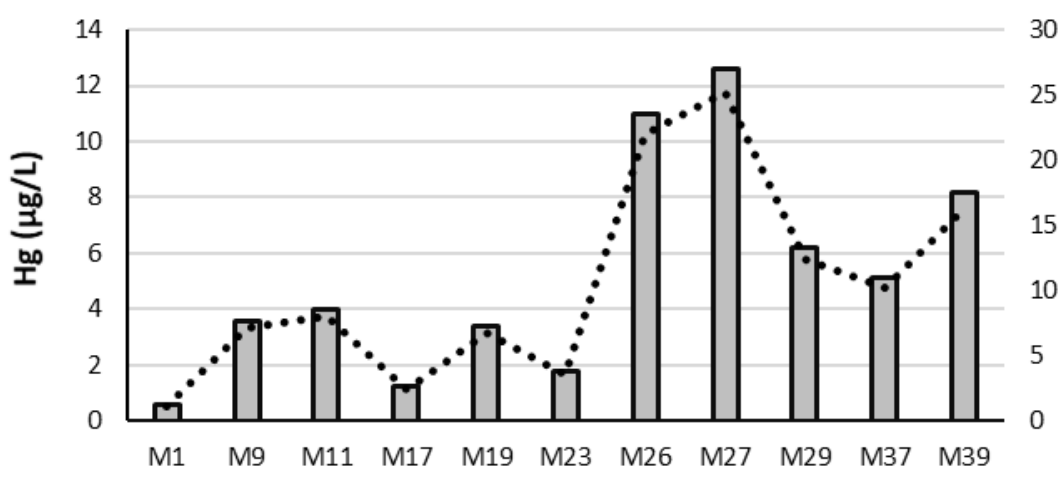

\section{Sampling Points}

$\square \mathrm{Hg}(\mu \mathrm{g} / \mathrm{L}) \quad \cdots \cdots \cdot \mathrm{CF}$

Figure 4. Contamination factor of $\mathrm{Hg}$ at the Black Sea Coast of Turkey (*The background value is selected according to the value at the farthest distance) 


\section{Conclusions}

The impact of anthropogenic $\mathrm{Hg}$ pollution in Black sea water was evaluated using Enrichment Factors (EF). Natural processes such as weathering and erosion of bedrocks are normally the main supply sources of heavy metals in fresh or sea water but it has been observed that the localized discharge from urban sewage, industrial effluents, ship emissions and oil spills significantly affects $\mathrm{Hg}$ biogeochemical cycle. However, few studies were carried out to investigate the $\mathrm{Hg}$ cycling in this region. With regard to an overall measure of $\mathrm{Hg}$ contamination applicable to estuarine or coastal water, the present study proposes a modified and generalized pollution impact by considering Black sea a closed water body. The results of the present study may provide useful information for an accurate assessment of the potential risk of $\mathrm{Hg}$ in the environment. Therefore, total $\mathrm{Hg}$ concentrations in environmental samples were determined, which is important for accurately performing ecological risk assessment (ERA) on $\mathrm{Hg}$ pollution.

In Black sea pollution impact at an individual location is best evaluated using enrichment factors. The results show that using the Fe concentration in the water as a normalizer produces minimal EF values for $\mathrm{Hg}$ even for sampling sites with considerable amount of $\mathrm{Hg}$, this shows that metals do not enrich into layers of water instead readily washed away or diluted. Overall, the range of contaminated factor values indicates a moderate to high degree of localized $\mathrm{Hg}$ pollution in mid Black sea. Same is the case with the direct sea samples which were detected with levels of $\mathrm{Hg}$ above permissible limits. This study revealed the need for further detailed metal enrichment assessment to decrease the uncertainty of discrimination between lithogenic and anthropogenic origins at the sites. Biological (fish samples) sediment and ecological studies need to be carried out in future studies to understand the influence of natural and anthropogenic factors.

\section{ACKNOWLEDGMENT}

This research has been funded by Ondokuz Mayis University, Turkey (Projet No. ÇEV.1901. 13.001).

\section{References}

Abdullah M.M., Ly A.R., Goldberg W.A., Clarke-Stewart K.A., Dudgeon J.V., Mull C.G., Chan T.J., Kent E.E., Mason A.Z. and Ericson J.E. (2012), Heavy metal in children's tooth enamel: related to autism and disruptive behaviors, J. Autism Dev. Disord., 42, 929-936.

Akbal F., Gürel L., Bahadır T., Güler İ., Bakan G. and Büyükgüngör H. (2011), Multivariate Statistical Techniques for The Assessment of Surface Water Quality at The Mid-Black Sea Coast of Turkey, Water, Air and Soil Pollution, 216(1-4), 21-37.

Altas L. and Buyukgungor H. (2007), Heavy Metal Pollution in The Black Sea Shore and Offshore of Turkey, Environ. Geo., 52, 469-476. DOI 10.1007/s00254-006-0480-1.

Al-Taani A.A., Batayneh A., Nazzal Y., Ghrefat H., Elawadi E. and Zaman H. (2014), Status of trace metals in surface seawater of the Gulf of Aqaba, Saudi Arabia, Marine Pollution Bulletin, 86(1), 582-590.
AMAP, (2011), AMAP Assessment 2011: Mercury in the Arctic. AMAP, Oslo, Norway.

Amyot M., Gill G.A. and Morel F.M. (1997), Production and Loss of Dissolved Gaseous Mercury in Coastal Seawater, Environmental Science and Technology, 31, 3606-3611.

Bakan G. and Buyukgungor H. (2000), The Black Sea, Marine Pollution Bulletin, 41, 24-43.

Bat L., Gokkurt O., Sezgin M., Ustun F. and Sahin F. (2009), Evaluation of the Black Sea Land Based Sources of Pollution the Coastal Region of Turkey, The Open Marine Biology Journal, 3,105-117.

Birch G.F. and Olmos M.A. (2008), Sediment-Bound Heavy Metals as Indicators of Human Influence and Biological Risk in Coastal Water Bodies, ICES J., 65, 1407-1413.

Bozcaarmutlu A., Sapmaz C., Aygun Z. and Arinc E. (2009), Assessment of Pollution in The West Black Sea Coast of Turkey Using Biomarker Responses in Fish, Marine Environmental Research, 67, 167-176.

Buddemeier R.W., Smith S.V., Swaney D.P. and Crossland C.J. (2002), The Role of the Coastal Ocean in the Disturbed and Undisturbed Nutrient and Carbon Cycles. LOICZ Reports \& Studies 24. Land-Ocean Interactions in the Coastal Zone, Texel, The Netherlands, 83.

Chakravarty M. and Patgiri A.D. (2009), Metal Pollution Assessment in Sediments of The Dikrong River, NE India, Journal of Human Ecology, 27(1), 63-67.

Chen C.W., Kao C.M., Chen C.F and Dong C.D. (2007), Distribution and Accumulation of Heavy Metals in The Sediments of Kaohsiung Harbor, Taiwan, Chemosphere, 66, 1431-1440.

Chen H., Wang J., Chen J., Lin H. and Lin C. (2016), Assessment of Heavy Metal Contamination in The Surface Sediments: A Reexamination Into The Offshore Environment in China, Marine Pollution Bulletin, http://dx.doi.org/10.1016/j.marpolbul.2016.08.079.

Cheng Z., Wang H.S., Du J., Sthiannopkao S., Xing G.H., Kim K.W., Yasin M.S.M., Hashim J.H. and Wong M.H. (2013), Dietary Exposure and Risk Assessment of Mercury via Total Diet Study in Cambodia, Chemosphere, 92, 143-149.

Christinal J. and Sumathi T. (2013), Effect of Bacopa Monniera Extract on Methylmercury Induced Behavioral and Histopathological Changes in Rats, Biol. Trace Elem. Res., 155(1), 56-64.

Compeau G.C. and Bartha R. (1987), Effect of salinity on mercurymethylating activity of sulfate-reducing bacteria in estuarine sediment, Appl. Environ. Microbial, 53, 261-265.

Cossa D., Martin J.M., Takayanagi K. and Sanjuan J. (1997), The Distribution and Cycling of Mercury Species in The Western Mediterranean, Deep Sea Research Part II: Topical Studies in Oceanography, 44(3-4), 721-740.

Costa M.F. and Liss P.S. (1999), Photoreduction of Mercury in Sea Water and Possible Geochemical Implications, Mar. Chem., 68, 87-95.

Costa M.F. and Liss P.S. (2000), Photoreduction and Evolution of Mercury from Seawater, Sci. Total Environ., 261, 125-135. [PubMed: 11036984].

Dan S.F., Umoh U.U. and Osabor V.N. (2014), Seasonal Variation of Enrichment and Contamination of Heavy Metals in The Surface Water of Qua Iboe River Estuary and Adjoining Creeks, South-South Nigeria, Journal of Oceanography and Marine Science, 5(6), 45-54. 
Du Laing G., Rinklebe J., Vandecasteele B., Meers E. and Tack F.M.G. (2009), Trace Metal Behaviour in Estuarine and Riverine Floodplain Soils and Sediments: A Review, Sci. Total Environ., 407, 3972-3985.

Ergul H.A., Topcuoglu S., Olmez E. and Kırbasoğlu C. (2008), Heavy Metals in Sinking Particles and Bottom Sediments from The Eastern Turkish Coast of The Black Sea, Estuarine, Coastal and Self Science, 78, 396-402.

Fisher J.A., Jacob D.J., Soerensen A.L., Amos H.M., Steffen A. and Sunderland E.M. (2012), Riverine Source of Arctic Ocean Mercury Inferred from Atmospheric Observations, Nat. Geosci., 5, 499-504.

Goodwin T.A., Smith P.K. and Parsons M.B. (2004), Multi-Element Distribution in Humus, Soil, Till, Rock and Tailings Associated with Historic Gold Districts of The Meguma Zone, Nova Scotia, Canada. In Mineral Resources Branch, Report of Activities 2003, Nova Scotia Department of Natural Resources, Report $\mathrm{ME}, 1,7-14$.

Guerra-Garcia J.M. and Garcia-Gomez J.C. (2005), Assessing Pollution Levels in Sediments of a Harbour with Two Opposing Entrances. Environmental Implications, J. Environ. Manage., 77, 1-11.

Guven K. C., Saygi N. and Ozturk B. (1993), Survey of Metal Contents of Bosphorus algea, Zostera Marina and Sediment, Botanica Marina, 36, 175-178.

Hakänson L. (1980), An Ecological Risk Index for Aquatic Pollution Control: A Sedimentological Approach, Water Res., 14, 975-1003.

Haris H. and Aris A.Z. (2013), The Geoaccumulation Index and Enrichment Factor of Mercury in Mangrove Sediment of Port Klang, Selangor, Malaysia Arab J. Geosci., 6, 4119-4128 DOI 10.1007/s12517-012-0674-7.

Heussner S., Monaco A., Fowler S.W., Buscail R., Millot C. and Bojanowski R. (1988), ECOMARGE: Flux of Particulate Matter in The Northwestern Mediterranean (Golfe du Lion). Oceanol. Acta. In: Minas, H.J., Nival, P. (Eds.), Océanographie pélagique méditerrannéenne, 149-154.

Hoda H.H.A. and Khaled A. (2009), Heavy Metals Contamination in Sediments of The Western Part of Egyptian Mediterranean Sea, Australian Journal of Basic and Applied Sciences, 3(4), 3330-3336.

Horvat M., Kotnik J., Logar M., Fajon V., Zvonarić T. and Pirrone N. (2003), Speciation of Mercury in Surface and Deep-Sea Waters in The Mediterranean Sea, Atmospheric Environment, 37(1), 93-108.

http://www.tuik.gov.tr/UstMenu.do?metod=temelist (01.02.2018).

http://eur-lex.europa.eu/legalcontent/EN/TXT/HTML/?uri=CELEX:32006R1881\&from=EN (01.02.2018).

Kibria G., Hossain M.M., Mallick D., Lau T.C. and Wu R. (2016), Monitoring of Metal Pollution in Waterways Across Bangladesh and Ecological and Public Health Implications of Pollution, Chemosphere, 165, 1-9.

Kim J.P. and Fitzgerald W.F. (1998), Gaseous Mercury Profiles in The Tropical Pacific Ocean, Geophys Res. Lett., 15, 40-43.

Kirk J.L., Lehnherr I., Andersson M., Braune B.M., Chan L., Dastoor A.P., Durnford D., Gleason A.L., Loseto L.L., Steffen A. and Louis V.L.St. (2012), Mercury in Arctic Marine Ecosystems: Sources, Pathways and Exposure, Environ. Res., 119, 64-87.
Ko L.Y.Y., Qin Y.Y. and Wong M.H. (2012), Heavy Metal Overloads and Autism in Children from Mainland China and Hong Kong: A Preliminary Study. In:Wong, M.H. (Ed.), Environmental Contamination e Health Risks and Ecological Restoration. Taylor and Francis/CRC, London.

Kothai P., Prathibha P., Saradhi I.V., Pandit G.G. and Puranik V.D. (2009), Characterization of Atmospheric Particulate Matter Using PIXE Technique, International Journal of Civil and Environmental Engineering, 1(1), 27-30.

Kotnik J., Horvat M., Tessier E., Ogrinc N., Monperrus M., Amouroux D., Fajon V., Gibičar D., Žižek S., Sprovieri F. and Pirrone N. (2007), Mercury Speciation in Surface and, Deep Waters of The Mediterranean Sea, Mar. Chem., 107(1), 13-30.

Lee B.S., Bullister J.L., Murray J.W. and Sonnerup R.E. (2002), Anthropogenic Chlorofluorocarbons in The Black Sea and Sea of Marmara, Deep-Sea Research, Part I, Oceanographic Research Papers, 49, 895-913.

Leopold K., Foulkes M. and Worsfold P. (2010), Methods for The Determination and Speciation of Mercury in Natural WatersA Review, Anal. Chim. Acta., 663(2), 127-138.

Lin Y.C., Chang-Chien G.P., Chiang P.C., Chen W.H. and Lin Y.C. (2013), Multivariate Analysis of Heavy Metal Contaminations in Seawater and Sediments from A Heavily Industrialized Harbor in Southern Taiwan, Marine Pollution Bulletin, 76(1), 266-275.

Loska K., Wiechula D., Barska B., Cebula E. and Chojnecka A. (2003), Assessment of Arsenic Enrichment of Cultivated Soils in Southern Poland, Poland Journal of Environmental Studies, 12(2), 187-192.

Man Y.B., Wu S.C. and Wong M.H. (2014), Shark Fin, A Symbol of Wealth and Good Fortune May Pose Health Risks: The Case of Mercury, Environ. Geochem Heal., 36, 1015-1027.

Mason R., Morel F., Egmond H. (1995), The Role Of Microorganisms in Elemental Mercury Formation in Natural Waters. Water, Air, and Soil Pollution, 80 775-787.

Manson R.P., Fitzgerald W.F., Hurley J., Hanson A.K., Donaghay Jr. P.L., Sieburth J.M. (1993), Mercury Biogeohemical Cycling in A Stratified Estuary, The American Society of Limnology and Oceanography, 36(6), 1227-1241.

Mason R.P., Sheu G.R. (2002), Role of The Ocean in The Global Mercury Cycle, Global Biogeochemical Cycles, 16, 1093.

Mashiatullah A., Chaudhary M.Z., Ahmad N., Javed, T.,Ghaffar A. (2013), Metal Pollution and Ecological Risk Assessment in Marine Sediments of Karachi Coast, Pakistan, Environmental Monitoring and Assessment, 185(2), 1555-1565.

Oste L., Zwolsman G. J., Klein J. (2012), Methods to Derive Natural Background Concentrations of Metals in Surface Water and Application of Two Methods in A Case Study, Watercycle Research Institute, Deltares B, 120611-005.

Power M., Klein G.M., Guiger K.R.R.A., Kwan M.K.H. (2002), Mercury Accumulation In The Fish Community Of A Sub-Artic Lake in Relation to Trophic Position and Carbon Sources, Journal of Applied Ecology, 39(5), 819-830.

Renault T. (2015), Immunotoxicological Effects of Environmental Contaminants on Marine Bivalves, Fish Shellfish Immunol., 46, 88-93.

Rhode Island Department of Health (RIDOH). (2016), Mercury poisoning: About fish. http://www.health.ri.gov/healthrisks/poisoning/mercury/ab out/fish/ Accessed 1 August 2016. 
Seshan B.R.R., Natesan U. and Deepthi K. (2010), Geochemical and Statistical Approach for Evaluation of Heavy Metal Pollution in Core Sediments In Southeast Coast of India, International Journal of Environmental Science and Technology, 7(2), 291-306.

Simex S.A. and Helz G.R. (1981), Regional Geochemistry of Trace Elements in Chesapeake Bay, Environmental Geology, 3, 315-323.

Sonke J.E., Heimburger L.E. and Dommergue A. (2013), Mercury Biogeochemistry: Paradigm Shifts, Outstanding Issues and Research Needs, C.R. Geoscience, 345, 213-224.

Srichandan S., Panigrahy R.C., Baliarsingh S.K., Rao S., Pati P., Sahu B.K. and Sahu K.C. (2016), Distribution of Trace Metals in Surface Seawater and Zooplankton of The Bay of Bengal, Off Rushikulya Estuary, East Coast of India, Marine Pollution Bulletin, 111(1), 468-475.

Sun R., Heimbürger L.E., Sonke J.E., Liu G., Amouroux D. and Berail S. (2013), Mercury Stable Isotope Fractionation in Six Utility Boilers of Two Large Coal-Fired Power Plants, Chemical Geology, 336, 103-111.

Sunderland E.M. and Mason R.P. (2007), Human Impacts on Open Ocean Mercury Concentrations, Global Biogeochem. Cycles, 21, GB4022.

Sutherland R.A., Tolosa C.A., Tack F.M.G. and Verloo M.G. (2000), Characterization of Selected Element Concentration and Enrichment Ratios in Background and Anthropogenically Impacted Roadside Areas, Archives of Environmental Contamination and Toxicology, 38, 428-438.

Tao H.C., Zhao K.Y., Ding W.Y., Li J.B., Liang P., Wu S.C. and Wong M.H. (2016), The Level of Mercury Contamination in Mariculture Sites at The Estuary of Pearl River and The Potential Health Risk, Environmental Pollution, http://dx.doi.org/10.1016/j.envpol.2016.07.067.

Tavares D.S., Lopes C.B., Daniel-da-Silva A.L., Vale C., Trindade T. and Pereira M.E. (2016), Mercury in River, Estuarine and Seawaters-Is It Possible To Decrease Realist Environmental Concentrations in Order To Achieve Environmental Quality Standards?, Water Research, 106, 439-449.

Topcuoglu S., Kirbasoglu C. and Gungor N. (2002), Heavy Metals in Organisms and Sediments From Turkish Coast of The Black Sea, 1997-1998, Environmental International, 27, 521-526.

Topcuoglu S., Ergul H.A., Baysal A., Olmez E. and Kut D. (2003), Determination of Radionuclide and Heavy Metal Concentrations in Biota and Sediment Samples From Pazar and Rize Stations in The Eastern Black Sea, Fresenius Environmental Bulletin, 12(7), 695-699.

Turekian K.K. and Wedepohl K.H. (1961), Distribution of The Elements in Some Major Units of The Earth's Crust, Geology Society of American Bulletin, 72(2), 175-192.

USEPA (United States Environmental Protection Agency), 1980, Ambient Water Quality Criteria for Mercury, EPA 440/5-80058. Washington, D.C.: Office of Water Regulations and Standards.

USEPA, (1997), Mercury Report to Congress, EPA-452/R-97-004. Washington, D.C.

US Food and Drug Administration (US FDA), (2016b). What You Need to Know About Mercury in Fish and Shellfish. US Food And Drug Administration, Washington, D.C., USA.

http://www.fda.gov/food/resourcesforyou/consumers/ucm1105 91.htm Accessed 1

August 2016.
Yigiterhan O. and Murray J.W. (2008), Trace Metal Composition of Particulate Matter of The Danube River and Turkish Rivers Draining Into The Black Sea, Marine Chemistry, 111, 63-76.

Yin S., Feng C., Li Y., Yin L. and Shen Z. (2015), Heavy Metal Pollution in The Surface Water of The Yangtze Estuary: A 5Year Follow-Up Study, Chemosphere, 138, 718-725.

Youssef M., El-Sorogy A. and Al-Kahtany K. (2016), Distribution of Mercury in Molluscs, Seawaters and Coastal Sediments of Tarut Island, Arabian Gulf, Saudi Arabia, Journal of African Earth Sciences, 124, 365-370.

Yucesoy F. and Ergin M. (1992), Heavy Metal Geochemistry of Surface Sediments from The Southern Black Sea Shelf and Upper Slope, Chemical Geology, 99, 265-287.

Zahra A., Hashni M.Z., Malik R.N. and Ahmed Z. (2014), Enrichment and Geo-Accumulation of Heavy Metals and Risk Assessment of Sediments of The Kurang Nallah-Feeding Tributary of The Rawal Lake Reservoir, Pakistan, Sci. Total Environ., 470-471, 925-933.

Zahir F., Rizwi S.J., Haq S.K. and Khan R.H. (2005), Low Dose Mercury Toxicity and Human Health, Environ. Toxicol. Pharmacol., 20(2), 351-360.

Zalewska T., Woroń Danowska B. and Suplińska M. (2015), Temporal Changes in $\mathrm{Hg}, \mathrm{Pb}, \mathrm{Cd}$ and $\mathrm{Zn}$ Environmental Concentrations in The Southern Baltic Sea Sediments Dated with 210Pb Method, Oceanologia, 57(1),32-43. 